\title{
EKSPERIMENTASI PENDEKATAN CTL BERBANTUAN MEDIA INNOVATIVE JAVANESE SONG DALAM MENGOPTIMALKAN KECERDASAN LINGUISTIK SISWA SEKOLAH DASAR
}

\author{
Dwiana Asih Wiranti ${ }^{1}$ dan Fitria Novita Sarie ${ }^{2}$ \\ ${ }^{1,2}$ Fakultas Tarbiyah dan Ilmu Keguruan UNISNU Jepara \\ Email: wiranti@uninu.ac.id ${ }^{1}$, fitria@ unisnu.ac.id $^{2}$
}

\section{Info Artikel}

Sejarah Artikel:

Diserahkan 3 September 2019

Direvisi 11 November 2019

Disetujui 18 November 2019

\section{Keywords:}

innovative javanese song, linguistic abilities learning outcomes in science

\section{Abstract}

The purpose of this study is to analyze the experimentation of CTL approach assisted by IJS (Innovative Javanese Song) media to optimize linguistic abilities and learning outcomes in science learning of elementary school students.

This study applies an experimental method to the type of non-equivalent control group design. There are two groups of students in the design of this study namely Al Islam Pengkol Elementary School students who were treated using the IJS media assisted CTL approach (X1) and Pengkol Elementary School 1 students who were treated using conventional learning (X2). The population of this research is elementary school students in Dabin 4, Jepara Regency. The sample technique used is purposive sampling. Data collection techniques using tests and nontest. The test is used to measure students' cognitive learning outcomes. The nontest technique is done by observation technique to collect linguistic intelligence score data. Data analysis uses quantitative descriptive analysis and qualitative descriptive analysis. The analytical method used to analyze data in the form of linguistic intelligence scores with descriptive percentages. To analyze student learning outcomes used gain score test.

The results showed a percentage of linguistic ability scores seen developing with CTL learning by IJS media. Student learning outcomes have also increased. Cognitive test results show an average classical completeness of 90-95\%. The gain score test results are 0.75 with a high category. The t-test results showed that the t-test was 8.619 , greater than the $t$-table that was 2.021 Affective learning outcomes show an average classical completeness of 80 $82 \%$. Psychomotor learning outcomes show an average classical completeness of $82 \%$. There are significant differences in linguistic abilities and learning outcomes in science learning with the CTL approach assisted by the IJS media. Therefore, the teacher can develop this media on learning with other material.

\footnotetext{
Abstrak

Tujuan penelitian ini yaitu menganalisis eksperimentasi pendekatan CTL berbantuan media IJS (Innovative Javanese Song) untuk mengoptimalkan kemampuan linguistik dan hasil belajar pada pembelajaran IPA siswa sekolah dasar.

Penelitian ini menerapkan metode eksperimen dengan tipe non-equivalent control group design. Ada dua kelompok siswa pada desain penelitian ini yaitu siswa SD Al Islam Pengkol yang diberi perlakuan menggunakan pendekatan CTL berbantuan media IJS ( $\left.\mathrm{X}_{1}\right)$ dan siswa SD Negeri 1 Pengkol yang diberi perlakuan menggunakan pembelajaran konvensional $\left(\mathrm{X}_{2}\right)$. Populasi penelitian ini yakni siswa sekolah dasar di Dabin 4 Kabupaten Jepara. Teknik sampel yang digunakan yaitu purposive sampling. Teknik pegumpulan data menggunakan tes dan nontes. Tes digunakan untuk mengukur hasil belajar kognitif peserta didik. Teknik nontes dilakukan dengan teknik observasi untuk mengumpulkan data skor kecerdasan linguistik. Analisis data menggunakan analisis deskriptif kuantitatif dan analisis deskriptif kualitatif. Metode analisis yang digunakan untuk menganalisis data berupa skor kecerdasan linguistik dengan deskriptif persentase. Untuk menganalisis hasil belajar peserta didik digunakan uji gain score.

Hasil penelitian menunjukkan persentase skor kemampuan linguistik terlihat berkembang dengan pembelajaran CTL berantuan media IJS. Hasil belajar peserta didik juga mengalami peningkatan. Hasil tes kognitif menunjukkan rata-rata ketuntasan klasikal sebesar 90-95\%. Hasil uji gain score sebesar 0,75 dengan kategori tinggi. Hasil uji t menunjukkan $t_{\text {hitung }}$ sebesar 8,619 lebih besar daripada $t_{\text {tabel }}$ yaitu 2,021. Hasil belajar Afektif menunjukkan ratarata ketuntasan klasikal sebesar $80-82 \%$. Hasil belajar psikomotor menunjukkan rata-rata ketuntasan klasikal sebesar $82 \%$. Terdapat perbedaan kemampuan linguistik dan hasil belajar yang signifikan pada pembelajaran IPA dengan pendekatan CTL berbantuan media IJS. Oleh karena itu, guru dapat mengembangkan media ini pada pembelajaran dengan materi yang lain.
} 


\section{PENDAHULUAN}

Permasalahan dalam pembelajaran selalu muncul seiring dengan perkembangan kurikulum dan kebutuhan siswa. Berdasarkan evaluasi hasil kelompok kegiatan guru (KKG) sekolah dasar di daerah binaan (dabin) 4 Kabupaten Jepara diketahui bahwa kemampuan berbahasa siswa pada kelas I SD masih kurang. Kemampuan berbahasa merupakan salah satu bagian dari kecerdasan linguistik yang harus dioptimalkan. Kurang optimalnya kecerdasan linguistik siswa terukur dari kurangnya kosakata bahasa Jawa krama dalam mengenali dan melakukan gerakan anggota tubuh.

Pembelajaran tematik mengintegrasikan beberapa mata pelajaran dalam satu waktu. Pembelajaran IPA dapat diintegrasikan dengan mata pelajaran bahasa Jawa. Bahasa jawa termasuk dalam mata pelajaran muatan lokal wajib di Jawa Tengah yang harus dikuasai siswa. Berdasarkan hasil wawancara dengan siswa di SD Al Islam Pengkol Jepara diketahui bahwa sebanyak $73 \%$ siswa kelas I belum bisa berbahasa Jawa krama dengan lancar. Padahal. sesuai dengan kepribadian orang Jawa, seseorang yang tidak bisa berbahasa Jawa krama mengindikasikan bahwa orang tersebut kurang memiliki sopan santun.

Untuk mengatasi permasalahan tersebut, penelitian ini berupaya memberikan solusi melalui pengembangan media Innovative Javanese Song (IJS). Media ini berisi tentang lagu anggota tubuh dan gerakannya dan dikemas dalam bentuk audio visual. Media IJS ini diaplikasikan menggunakan pendekatan Contextual Teaching Learning (CTL) dalam proses pembelajarannya.

Pendekatan Contextual Teaching Learning (CTL) merupakan pendekatan dengan menyesuaikan konteks atau kondisi peserta didik. Guru menyesuaikan kebutuhan peserta didik sesuai dengan kemampuan, potensi daerah maupun materi pembelajaran. Hasil penelitian Shamsid dan Bettye (2006) menemukan bahwa pembelajaran kontekstual dapat memberikan gambaran kepada guru untuk memberikan konsep baru dalam pembelajaran. Guru bisa menerapkan pendekatan ini dengan berbagai metode, strategi, dan media pembelajaran.

Dalam penelitian ini, pendekatan CTL diaplikasikan dengan dukungan media pembelajaran Innovative Javanese Song (IJS) yang isi dan bahasanya dikemas secara kontekstual sesuai dengan ruang lingkup peserta didik kelas I SD. Winarti (2015) menyatakan bahwa pendekatan CTL bermanfaat untuk mengembangkan masing-masing aspek kecerdasan majemuk. Melalui pendekatan ini, prestasi belajar peserta didik lebih meningkat dibandingkan dengan pembelajaran langsung atau konvensional. Penelitian tersebut yang melatarbelakangi dipilihnya pendekatan CTL.

Media IJS yang digunakan dalam penelitian ini merupakan media pembelajaran inovatif yang diadopsi dari hasil penelitian Sarie (2016) yang menyatakan bahwa lagu dapat meningkatkan multiple intelligence siswa. Pada kecerdasan musikal menunjukkan perkembangan sebesar $75 \%$ dan pada kecerdasan linguistik meningkat sebesar $85 \%$. Meskipun sama-sama menggunakan pendekatan CTL untuk mengoptimalkan kecerdasan siswa, tetapi penelitian ini tetap memiliki perbedaan dengan penelitian yang telah dilakukan oleh Sarie (2016) tersebut. Perbedaannya terletak pada fokus peneltian. Penelitian Sarie (2016) menganalisis seluruh kecerdasan majemuk siswa, sedangkan penelitian ini hanya berfokus pada optimalisasi kecerdasan linguistik siswa saja.

Media IJS ini dikemas dalam bentuk lagu anak. Lagu anak memiliki melodi, irama, dan ritme yang sederhana, sehingga mudah dipelajari (Kamtini dan Tanjung, 2005). Musik yang indah menjadi hiburan bagi manusia, karena musik dapat menjadikan orang senang, gembira, dan nyaman. Aristoteles (dalam Rachmawati, 2009) menyatakan bahwa musik adalah tiruan seluk beluk hati dengan menggunakan melodi dan irama. Dinamakan Innovative Javanese Song (IJS) karena lagu dalam media ini menggunakan bahasa Jawa krama yang isinya tentang anggota tubuh dan gerakannya.

Pilihan bahasa Jawa krama dalam lirik lagu ini dipilih untuk dapat menstimulus perkembangan kecerdasan linguistik siswa dalam menunggakan bahasa Jawa krama pada kehidupan sehari-hari. Bahasa Jawa merupakan bahasa yang mengenal adanya tingkat tutur atau unggah-ungguh (Sutardjo, 2012). Tingkat tutur bahasa merupakan suatu kekayaan budaya yang dimiliki oleh beberapa suku di Indonesia, terutama suku Jawa (Sasangka, 2010). Tingkat tutur tersebut tampak pada adanya perbedaan penggunaan kata berdasarkan penutur. Sebagai contoh, pilihan kata 'kepala' jika dituturkan untuk orang yang lebih tua menjadi 'mustaka', tetapi jika dituturkan kepada orang yang lebih muda menjadi 'sirah'.

Melalui media IJS, kecerdasan linguistik anak dalam berbahasa Jawa krama akan distimulasi. Gardner (2011) menjelaskan bahwa kecerdasan linguistik merupakan kemampuan 
individu dalam bidang bahasa atau kata. Aktivitas pendukung yang relevan dengan usaha meningkatkan kecerdaaan linguistik yakni dengan kegiatan instruksi, membaca, berdiskusi, berdebat, memberikan pendapat, dan menyimak.

Media IJS selain tentang anggota tubuh juga disertai dengan gerakannya menggunakan bahasa Jawa. Contohnya, manthuk-manthuk, mengleng, njenthir, ndhodhok, dan keprok. Dengan demikian, media IJS ini dapat digunakan untuk mendemonstrasikan dan menugaskan anak melakukan gerakan anggota tubuh. Dimana kegiatan demontrasi dan penugasan membuat siswa lebih termotivasi dan ekspresif dalam meningkatkan kecerdasan majemuk anak (Delaney dan Shafer, 2007).

Kecerdasan linguistik merupakan bagian dari kecerdasan majemuk yang dimiliki setiap anak. Gardner (2011) menyatakan bahwa kecerdasan seseorang mencakup serangkaian kecerdasan yang terdiri atas sembilan macam kecerdasan yang disebut sebagai kecerdasan majemuk (multiple intelligence). Jenis kecerdasan tersebut meliputi kecerdasan naturalis, matematik, musikal, visual-spasial, interpersonal, intrapersonal, eksistensial, linguistik dan kinestetik. Apabila kecerdasan majemuk ini dikembangkan dalam satu pembelajaran, maka akan meningkatkan evektivitas dan kualitas pembelajaran itu sendiri.

Berbagai peneletian berkaitan dengan optimalisasi kecerdasan majemuk dalam satu pembelajaran telah banyak dilakukan. Xie dan Lin (2009) membuktikan bahwa pembelajaran multiple intelligence efektif dilakukan dalam pembelajaran di Polytechnic University. Optimalisasi kecerdasan majemuk dapat dilakukan dengan memanfaatkan fasilitas sekolah, dan lingkungan sekolah (Griggs et al. 2009).

Dalam upaya yang sama, penelitan ini mengembangkan sebuah media IJS untuk mengoptimalkan kecerdasan majemuk siswa. Akan tetapi, berkaca pada hasil observasi ditemukan bahwa guru SD di dabin 4 Kabupaten Jepara memerlukan solusi untuk dapat mengoptimalkan kecerdasan linguistik pada siswa kelas I SD. Oleh sebab itu, peneltian ini berfokus pada optimalisasi kecerdasan linguistik saja.

Pembelajaran CTL berbantuan IJS dapat diimplementasikan dengan cara melibatkan peserta didik dalam mempelajari materi IPA melalui berbagai aktivitas kegiatan dan diharapkan dapat mengoptimalkan kecerdasan linguistik peserta didik, yang berdampak pula pada peningkatan hasil belajar pada mata pelajaran IPA.

\section{METODE PENELITIAN}

Penelitian ini merupakan penelitian eksperimen yang melibatkan kelas eksperimen dan kontrol. Desain penelitian menggunakan non-equivalent control group design.

Tabel 1. Desain Penelitian Eksperimen

\begin{tabular}{lccc}
\hline Kelompok & Pretes & Treatment & Posttest \\
\hline Eksperimen & $\mathrm{O}_{1}$ & $\mathrm{X}_{1}$ & $\mathrm{O}_{2}$ \\
Kontrol & $\mathrm{O}_{1}$ & $\mathrm{X}_{2}$ & $\mathrm{O}_{2}$ \\
\hline
\end{tabular}

$\mathrm{O}_{1}=$ Pretes

$\mathrm{O}_{2}=$ Posttest

$\mathrm{X}_{1}=$ perlakuan di dalam kelompok eksperimen menggunakan pendekatan CTL berbantuan media IJS

$\mathrm{X}_{2}=$ perlakuan di dalam kelompok kontrol menggunakan pembelajaran konvensional.

Ada dua kelompok di dalam desain penelitian ini. Kelas pertama yang terletak di SD Al Islam Pengkol diberi perlakuan menggunakan pembelajaran dengan menerapkan pendekatan CTL berbantuan media IJS $\left(\mathrm{X}_{1}\right)$ dan kelas di SD Negeri 1 Pengkol menggunakan pembelajaran secara konvensional $\left(\mathrm{X}_{2}\right)$.

Populasi pada penelitian ini yakni siswa sekolah dasar di Dabin 4 Kabupaten Jepara. Teknik sampel yang digunakan adalah purposive sampling, sekolah yang diambil yakni SD AlIslam Pengkol sebagai kelas eksperimen dan SD N 1 Pengkol sebagai kelas kontrol. Teknik pegumpulan data menggunakan tes dan nontes. Tes dalam penelitian ini digunakan untuk mengukur hasil belajar kognitif peserta didik. Teknik nontes dilakukan dengan teknik observasi. Observasi dilakukan untuk mengumpulkan data skor kecerdasan linguistik.

Analisis data menggunakan analisis deskriptif kuantitatif dan analisis deskriptif kualitatif. Metode analisis yang digunakan untuk menganalisis data berupa skor kecerdasan linguistik dengan deskriptif persentase. Untuk menganalisis hasil belajar peserta didik digunakan uji gain score. Untuk menganalisis respon siswa menggunakan deskriptif kualitatif. Adapun untuk menguji implementasi pendekatan CTL berbantuan media IJS dalam mengoptimalkan kecerdasan linguistic dan hasil belajar peserta didik digunakan uji t satu sampel. 
Dwiana Asih Wiranti dan Fitria Novita Sarie

EKSPERIMENTASI PENDEKATAN CTL BERBANTUAN MEDIA INNOVATIVE JAVANESE SONG ... REFLEKSI EDUKATIKA : Jurnal Ilmiah Kependidikan 10 (1) Desember 2019. Hlm. 58-64

\section{HASIL DAN PEMBAHASAN}

Secara keseluruhan kecerdasan linguistik peserta didik pada kelas eksperimen memperoleh skor yang tinggi dan masuk dalam kategori baik, sedangkan pada kelas kontrol cenderung rendah dan masuk dalam kategori kurang. Kelompok yang diberi perlakuan menggunakan media IJS memiliki nilai mean sebelum dan sesudah sebesar 6,148 dan 14,000. Dengan demikian, pada kelompok yang diberi perlakuan menggunakan media Ijs mengalami peningkatan sebesar 7, 825 poin.

Tabel 1. Data Paired Samples Statistics

\begin{tabular}{cccccc}
\hline & & Mean & $\mathbf{N}$ & $\begin{array}{l}\text { Std. } \\
\text { Dev] }\end{array}$ & $\begin{array}{l}\text { Std. } \\
\text { Error } \\
\text { Mean }\end{array}$ \\
& & & & & \\
$\begin{array}{c}\text { Pair } \\
\mathbf{1}\end{array}$ & Sesudah & 6,148 & 27 & .7181 & .1382 \\
& Sebelum & $\begin{array}{l}14,00 \\
0\end{array}$ & 27 & .8321 & .1601 \\
\hline
\end{tabular}

Sumber. Data Hasil Penelitian

Adapun perolehan skor dan kriteria anak yang diberikan perlakuan menggunakan media IJS saat pretest dan postes sebagai berikut.

Tabel 2. Hasil Pretes dan Postes

\begin{tabular}{|l|l|l|l|l|l|l|}
\hline Skor & $\begin{array}{l}\text { Rentang } \\
\text { Nilai }\end{array}$ & Kriteria & Pretes & & Postes & \\
\hline 1 & $1-5$ & $\begin{array}{l}\text { Tidak } \\
\text { Baik }\end{array}$ & 9 & 33 & 0 & 0 \\
\hline 2 & $6-10$ & $\begin{array}{l}\text { Kurang } \\
\text { Baik }\end{array}$ & 10 & 37 & 8 & 29 \\
\hline 3 & $11-15$ & Baik & 3 & 11 & 5 & 19 \\
\hline 4 & $16-20$ & $\begin{array}{l}\text { Sangat } \\
\text { Baik }\end{array}$ & 5 & 19 & 14 & 52 \\
\hline
\end{tabular}

Berdasarkan hasil tabel tersebut saat dilakukan pretes, sebanyak 9 anak (33\%) berada pada kriteria Tidak Baik, sembilan anak tersebut belum bisa menyebutkan anggota tubuh dengan bahasa Jawa krama. Sebanyak 10 anak (37\%) berada pada kriteria Kurang Baik. 10 anak tersebut sudah bisa menyebutkan 1 anggota tubuh. Selanjutnya ada 3 anak $(11 \%)$ yang berada pada rentang Baik, yakni anak sudah bisa menyebutkan 2 anggota tubuh menggunakan bahasa Jawa krama, serta 5 anak $(19 \%)$ berada pada rentang Sangat Baik. Kelima anak ini sudah bisa menyebutkan lebih dari 5 anggota tubuh menggunakan bahasa Jawa krama.

Hasil postes menunjukkan bahwa tidak satupun anak yang berada pada kriteria Tidak Baik. Artinya setelah dilakukan treatment, kemampuan linguistik anak dalam menyebutkan anggota tubuh menggunakan bahasa Jawa krama meningkat. Semua anak sudah bisa melakukan menyebutkan. Meskipun, ada kriteria lain yang belum sempurna $100 \%$ meningkat. Ada 8 anak atau 29\% yang berada pada rentang Kurang Baik. Maksudnya, 8 anak ini baru bisa menyebutkan satu anggota tubuh menggunakan bahasa Jawa krama. Kemudian, sebanyak 5 anak (19\%) berada pada rentang Baik. Dikatakan baik, karena pada kriteria ini anak telah mampu menyebutkan 2 anggota tubuh menggunakan bahasa Jawa krama. Selanjutnya sebanyak 14 anak $(52 \%)$ berada pada rentang Sangat Baik, dimana anak sudah bisa menyebutkan 3 atau lebih anggota tubuh menggunakan bahasa Jawa krama. Dari hasil tersebut dapat disimpulkan bahwa mayoritas pada saat postes kemampuan anak berada pada kriteria Kurang Baik dan kriteria Sangat Baik saat dilakukan postes.

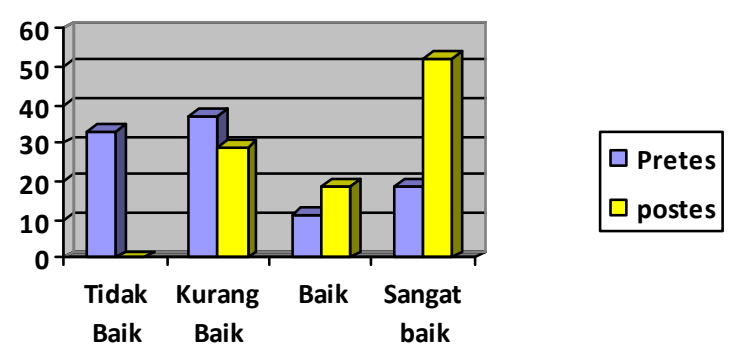

Gambar 1. Grafik Hasil Belajar pada saat Pretest dan Posttest.

Dari gambar grafik tersebut dapat diketahui bahwa hasil belajar anak setelah dilakukan treatment melalui pendekatan CTL berbantuan media IJS meningkat. Pada saat pretest persentase kemampuan anak paling banyak terletak pada kriteria mulai berkembang. Setelah dilakukan treatment, pada saat posttes meningkat menjadi criteria berkembang sangat baik yang paling tinggi.

Terdapat perbedaan rata-rata hasil pretest dan posttest. Setelah dilakukan treatment, anakanak melakukan posttest dan hasilnya menunjukkan adanya peningkatan kecerdasan linguistik anak dalam berbahasa Jawa krama. 
Dibuktikan dengan anak yang telah mampu mencapai indikator keberhasilan kecerdasan linguistik. Mampu menyebutkan anggota tubuh dengan bahasa Jawa karma, menunjuk letak bagian tubuh sesuai nama anggota tubuh dengan bahasa Jawa karma,dan menyebutkan manfaat anggota tubuh dengan bahasa Jawa krama. Selain itu, anak mampu memilih anggota tubuh sesuai dengan anggota tubuh yang disebutkan melalui bahasa Jawa krama. Hal ini menunjukkan bahwa media IJS efektif dalam pengembangan kecerdasan linguistik siswa sekolah dasar.

Tabel 3. Uji Perbandingan Kemampuan Linguistik Siswa Sebelum Dan Sesudah Menggunakan Pendekatan CTL Berbantuan IJS

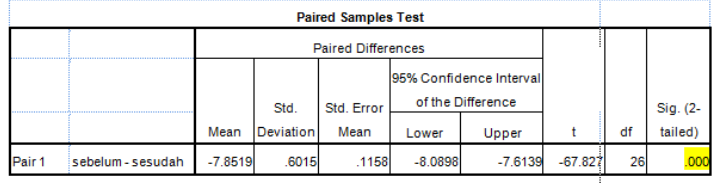

Analisis:

a.hipotesis

$\mathrm{H} 0$ :tidak terdapat perbedaan rata-rata kemampuan linguistik sebelum dan sesudah dilakukan media pembelajaran IJS.

HI: terdapat perbedaan rata-rata kemampuan linguistik sebelum dan sesudah dilakukan media pembelajaran IJS.

b.taraf signifikansi

$\alpha=5 \%$ atau $\alpha=0.05$

a. kriteria penolakan

$\mathrm{H} 0$ ditolak jika nilai signifikasi $<\alpha$

b. keputusan dan kesimpulan

karena nilai signifikansi pada output spss $<\alpha$ atau $0.000<0.05$, maka H0 ditolak. Jadi terdapat perbedaan ratarata kemampuan linguistik sebelum dan sesudah dilakukan media pembelajaran IJS.

Data diatas dapat disimpulkan bahwa terdapat perbedaan rata-rata kemampuan linguistik sebelum dan sesudah dilakukan pembelajaran dengan pendekatan CTL berbantuan media IJS. Berdasarkan ketentuan yang berlaku, maka dapat disimpulkan bahwa ada perbedaan hasil belajar yang signifikan antara siswa pada kelas eksperimen yang menggunakan pendekatan CTL berbantuan IJS dan siswa kelas kontrol yang menggunakan pendekatan langsung dengan metode diskusi dan demonstrasi. Perbedaan tersebut terjadi setelah dilakukan treatment, anak-anak melakukan posttest dan hasilnya menunjukkan adanya peningkatan kecerdasan linguistik anak dalam berbahasa Jawa krama. Dibuktikan dengan anak yang telah mampu mencapai indikator keberhasilan kecerdasan linguistik. Seperti mampu menyebutkan anggota tubuh dengan bahasa Jawa krama. menunjuk letak bagian tubuh sesuai nama anggota tubuh dengan bahasa Jawa karma dan menyebutkan manfaat anggota tubuh dengan bahasa Jawa krama. Selain itu, anak mampu memilih anggota tubuh sesuai dengan anggota tubuh yang disebutkan dengan bahasa Jawa krama. Hal ini menunjukkan bahwa media IJS efektif dalam pengembangan kecerdasan linguistik siswa sekolah dasar.

Penelitian ini juga menganalisis respon siswa terhadap pembelajaran dengan pendekatan CTL berbantuan media IJS. Data respon anak diambil sebagai bahan pembanding bahwaa perlakuan yang diberikan peneliti kepada anakanak tidak jauh berbeda antarkelompok satu dan lainnya. Adapun data respon anak adalah sebagai berikut.

Tabel 3. Hasil Respon Anak

\begin{tabular}{|l|l|l|}
\hline Kriteria & $\sum$ & $\%$ \\
\hline $\begin{array}{l}\text { Mau belajar menggunakan } \\
\text { media IJS }\end{array}$ & 16 & $59.25 \%$ \\
\hline $\begin{array}{l}\text { Senang belajar menggunakan } \\
\text { media IJS }\end{array}$ & 21 & $77.77 \%$ \\
\hline Media IJS menarik & 23 & $85.18 \%$ \\
\hline Media IJS mudah & 20 & $74.07 \%$ \\
\hline $\begin{array}{l}\text { Mau Belajar dengan media } \\
\text { IJS lagi }\end{array}$ & 16 & $59.25 \%$ \\
\hline
\end{tabular}

Sumber: Data hasil penelitian

Berdasarkan tabel tersebut, anak-anak yang diberi kegiatan pembelajaran menggunakan media IJS memberikan respon yang baik karena secara keseluruhan siswa menjawab beberapa kriteria dengan hasil positif di atas $50 \%$. Sejumlah $59.25 \%$ siswa menyatakan mau belajar menggunakan media IJS karena mereka mengaku bahwa sebelumnya belum pernah mengenal media IJS. Setelah menggunakan media IJS, 21 siswa atau $77.77 \%$ siswa merasa senang ketika media IJS digunakan dalam pembelajaran, bahkan $85.18 \%$ mengatakan media IJS menarik. Berikutnya terdapat 20 siswa atau sebesar $74,07 \%$ siswa merasa media IJS mudah untuk dipahami dan dipelajari. Terdapat 16 anak yang juga ingin untuk belajar dengan media IJS lagi. 


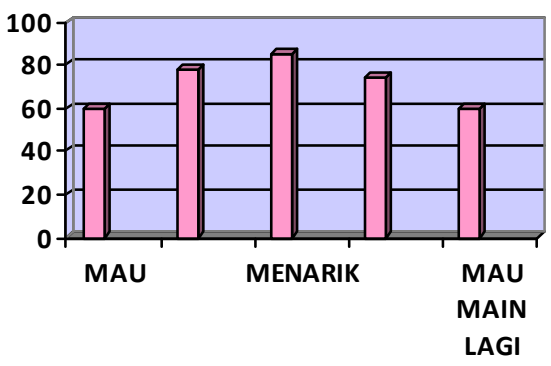

Gambar 2. Grafik Respon Anak

Berdasarkan grafik tersebut, nampak bahwa hasil respon tertinggi berada pada kriteria media IJS menari bagi siswa. Ini sangat relevan bahwa media lagu lebih menarik daripada konvensional atau menghafal. Sementara itu respon yang memiliki nilai terendah yakni kriteria mau atau tidak belajar menggunakan media IJS. Hal ini sangat wajar karena media IJS sangat asing bagi siswa. Selama ini, siswa belum pernah mempelajari anggota tubuh dengan bahasa Jawa krama menggunakan lagu yang disertai dengann animasi gerakan tubuh.

Berdasarkan hasil respon tersebut dapat disimpulkan bahwa media IJS mendapatkan respon baik bagi siswa sekolah dasar. Mereka menyatakan merasa senang dalam belajar anggota tubuh dengan bahasa Jawa krama. Melalui lagu berbahasa Jawa krama yang dilengkapi dengan animasi gerak tubuh, menarik bagi siswa. Hasilnya, mereka merasa mudah dalam memperlajari anggota tubuh dengan bahasa Jawa krama yang disertai dengan gerakannya dalam bahasa Jawa krama pula.

Dengan demikian, media IJS terbukti dapat membedakan gerak tubuh menggunakan bahasa Jawa dan mempraktikkannya. Astuti (2015) dalam penelitiannya membuktikan bahwa lagu anak dapat membantu anak mempelajari perilaku sosial. Seperti halnya penelitian ini, diharapkan melalui kegiatan menyimak dan menyanyikan lagu anak berbahasa Jawa krama, anak dapat menyebutkan anggota tubuh menggunakan bahasa Jawa krama. Dengan demikian, jika anak mampu untuk membedakan bahasa Jawa krama mengenai anggota tubuh dan mampu menerapkannya jika berbicara dengan orang yang lebih tua maka sikap sopan santun anak semakin baik dan media IJS juga dapat member kontribusi dalam membantu anak menguasai bahasa Jawa krama terutama tentang anggota tubuh.

Hasil penelitian yang dilakukan memiliki persamaan dan perbedaan dengan riset Astuti (2015), Fatonah (2009), Irvaniyah (2014),
Tanfidiyah (2019), dan Yanto (2015). Adapun persamaannya yaitu pada topik mengenai kecerdasan linguistik dan muatan IPA. Sementara itu perbedaanya pada fokus penelitian sehingga hasil risetnya berbeda.

\section{SIMPULAN}

Pendekatan CTL berbantuan media IJS diketahui mampu mengoptimalkan kecerdasan linguistik dan hasil belajar peserta didik kelas I SD pada pembelajaran IPA. Optimalnya kecerdasan linguistik peserta didik dapat dilihat berdasarkan indikator keberhasilan kecerdasan linguistik yakni mampu menyebutkan anggota tubuh dengan bahasa Jawa karma, menunjuk letak bagian tubuh sesuai nama anggota tubuh dengan bahasa Jawa karma, menyebutkan manfaat anggota tubuh dengan bahasa Jawa krama. Anak juga mampu memilih anggota tubuh sesuai dengan anggota tubuh yang disebutkan dengan bahasa Jawa krama. Hal ini menunjukkan bahwa media IJS efektif dalam pengembangan kecerdasan linguistik siswa sekolah dasar.

\section{DAFTAR PUSTAKA}

Astuti, Tri Puji. 2015. Pengaruh Pemberian Lagu Anak-Anak terhadap Perilaku Prososial Siswa Taman Kanak-Kanak. Jurnal Empati, 4: 101-106.

Eberle, SG. 2011. "Playing with the Multiple Intelligences, How Play Helps Them Grow". American Journal of Play, 4 (1): 19-51.

Fatonah, Siti. 2009. Menumbuhkan Kecerdasan Majemuk (Multiple Inteligences Anak dengan Mengenal Gaya Belajarnya dalam Pembelajaran IPA SD. Jurnal Al-Bidayah, 1 (2).

Gardner, H. John, \& Hpbbs, E. (Ed). 2011. Frames of Mind: The Theory of Multiple Intelligences. New York: Basic Books.

Griggs LA, S Barney, JB Sederberg, E Collins, S Keith \& L Iannaci. 2009. "Varying Pedagogy to Address Student Multiple Intelligences." Journal of the Sociology of Self-Knowladge, 7 (1): 55-60.

Irvaniyah, Iyan dan Akbar, Reza Oktaviana. 2014. Analisis Kecerdasan Logis Matematis dan Kecerdasan Linguistik 
Siswa Berdasarkan Jenis Kelamin(Studi Kasus Pada Siswa Kelas XI IPA MA Mafatihul Huda). EduMa, 3 (1): 138-150.

Ozdemire P, Guneysu \& Tekkaya. 2016. "Enhancing Learning through Multiple Intelligences." Journal of Biological Education, 40 (2): 74-78.

Rachmawati. 2009. Musik sebaagai Pembentuk Budi Pekerti. Bandung: Panduan.

Sarie, Fitria Novita. 2016. Implementasi Pendekaran CTL bervisi SETS dalam Mengoptimalkan Multiple Intelligence dan Hasil Belajar. Journal of Primary Education, 5 (2): 81-87.

Tanfidiyah, Nur dan Utama. Ferdian. 2019. Mengembangkan Kecerdasan Linguistik Anak Usia Dini Melalui Metode Cerita. GOLDEN AGE Jurnal Ilmiah Tumbuh Kembang Anak Usia Dini 4 (3): 9-18.
Triaji, Choirudin Lutfi., Yayuk, Erna., dan Fithriyanasari. 2019. Contextual Teaching And Learning Untuk Peningkatan Keterampilan Menulis Narasi Siswa Kelas IV Sekolah Dasar. Refleksi Edukatika : Jurnal Ilmiah Kependidikan, 9 (2): 134140.

Winarti, Atiek, dkk. 2015. Pengembangan Model Pengembangan "Cerdas" berbasis Teori Multiple Intelligences pada Pembelajaran IPA. Jurnal Kependidikan, 45: 16-28.

Xie dan Lin. 2009. "Research on Multiple Intelligences Teaching and Assessment". Asian Journal of Management and Humanity Sciences, 4 (2-3): 106-124.

Yanto, Yanto dan Ruhenda, Ruhenda. 2015. Hubungan Antara Kecerdasan Linguistik Dan Motivasi Belajar Dengan Hasil Belajar Bahasa Indonesia Siswa Kelas VI di SDN Cihideung Ilir 04 Kecamatan Ciampea. Jurnal Teknologi Pendidikan, 4 (2). 